problem for the best part of two years. The study is the eighth to have been carried out in the series of studies of national science policies in the 21 member nations of the OECD, but the chances are great that the special circumstances of the United States will bring up questions which earlier reports in the series have not raised. Prominent among these are likely to be questions related to what is sometimes called the technology gap-a cause known to be close to the heart of the OECD. Not merely is there likely to be a serious attempt to draw from American experience in the management of science and technology, but there is also likely to be some attempt to determine the wisdom of trying to follow in Europe some of the developments which have been prominent in the United States in recent years.

The OECD report, which is the basis for the discussions being held in Paris, has been prepared partly by the secretariat of the OECD and partly by a panel which consists of Dr H. G. B. Casimir, director of the Philips Research Laboratories at Eindhoven; $\mathbf{M r}$ Theo Lefevre, a former prime minister of Belgium; M. Pierre Masse, chairman of Electricité de France; and Professor C. H. Waddington of the University of Edinburgh. A full summary of the review of United States Science Policy, together with an account of the confrontation in Paris, will appear in Nature next week.

\section{Drugs' Dark Days}

THe United States pharmaceutical industry must be suffering from a bad case of nostalgia. The good old days of the nineteen-fifties - when wonder drugs brought wondrous profits and gratitude from the public as well-are probably gone for ever. Instead, the federa] government is getting more and more inquisitive about the whole business of medicines: how much they cost to make, whether they perform as advertised, whether those with melodious trade names are better healers than those with clumsy generic names. Two Senate investigations are now in progress, one looking into possible abuses in the diet pill industry, another into the pricing policies of drug manufacturers. The total government spending on drugs by federal, state and municipal authorities continues to increase-it is now $\$ 200$ million a year-so that the authorities are now unlikely to relax their vigilance.

The aura of suspicion created by Senate investigators was even blamed by an executive of one of the pharmaceutical firms found guilty last week for conspiring to control the production and sales of tetracycline. Certainly the jury had a lot to contend with-patent law, chemical formulae, patent and anti-trust laws were all freely quoted during the trial. Their finding that three companies-Charles Pfizer and Company, American Cyanamid Company and the Bristol Myers Company-are guilty of criminal conspiracy in monopolizing the manufacture of tetracycline until 1961 has shaken the industry. The decision, if it is not reversed, opens the door to lawsuits from major purchasers of tetracycline from the defendants. The City of New York and the State of Florida have already filed their suits in the hope of recovering the treble damages allowed by the Sherman Anti-Trust Act against companies convicted of monopoly. The sums eventually paid back to irate customers could exceed those awarded a few years ago when some American electrical companies were convicted of price-fixing.

The industry, not surprisingly, feels hard done by The big laboratories, as the argument goes, bear the costs of all the research and, as soon as they come up with something useful, smaller companies rush in, copy the medicine and sell it at cut-prices. Are the better-known branded products more efficacious? The big companies say they are, and many doctors, including some from the American Defense Department, which has been buying low-priced tetracycline from Italy rather than the expensive domestic brands, agree. The Food and Drug Administration set up a special committee to study the problem of efficacy and equivalence; and the job is harder than anyone had thought. After eighteen months, the committee has asked for more time.

The debate has really just begun. Last year in Congress Senator Long of Louisiana tried to make it mandatory for all public agencies in the medicinebuying business to buy drugs by their chemical rather than by their trade names. He failed, but a vestige of his wish survived in the form of a directive to the Department of Health, Education and Welfare to ask all state governments to promise that the medicines that they were buying for people on relief rolls was purchased at the lowest possible cost. At the very least, this means that more attention will be paid to the question of getting best buys. The price differences between what are said to be equal quantities of the same compound are staggering. The Senate is hearing that public agencies were charged \$2.09 in one case and $\$ 160$ in another for the same quantity of reserpine tablets, and the Justice Department's complaint in the tetracycline case was that antibiotic tablets costing $\$ 2$ or $\$ 3$ a hundred to produce were being sold to the customer at $\$ 51$ a hundred.

Meanwhile, the FDA is getting ready to make public the results of its inquiry into the efficacy of medicines sold in America between 1938 and 1962, when stricter standards were established. The advance reports say that about 10 per cent of the old favourites in the medicine cabinet could be denounced as worthless and some may have to be withdrawn from sale.

\section{Computers More Expensive}

InTERnationaL Business Machines last week announced increases in the cost of both buying and renting its computers in Britain. Renting an IBM machine will cost 10 per cent more, while buying one will cost up to 10 per cent more. The hiring of time at computer bureaux and data centres will go up by between 3 and 10 per cent, and maintenance charges will increase by 4 per cent. These increases, a response to the devaluation of sterling, may well be duplicated by other computer companies which use a large proportion of imported parts - a group which includes every computer manufacturer in Britain, with the possible exception of International Computers and Tabulators.

IBM has also taken the opportunity of announcing a new computer, as part of the 360 series. The new model, the $360 / 25$, falls between the smallest machine in the IBM range, the $360 / 20$, and the next up, the $360 / 30$. It will offer users of the $360 / 20$ a chance to increase their computing power without having to 
learn a new language, and competitive pricing should help to encourage buyers. These moves come at a time of unprecedented weakness for IBM in the British market-it has even been suggested that IBM's share of the British market has fallen below 30 per cent. Whether or not this is true--IBM always refuses to divulge its market share - it is certainly true that Britain is proving a tougher market than some others. Because IBM does most of its production for Europe in France and West Germany, the effects of devaluation are likely to hit the company harder than others. Honeywell, which produces computers at its factory in Scotland, will be cheered by devaluation. ICT, on the other hand, still views the effects of devaluation with some suspicion. Colonel A. T. Maxwell, chairman of the company, presenting the annual report for 1967 , said that the effect of the measures was still not clear. "We are inevitably faced with higher costs, but we shall so direct our affairs as to contain these as much as possible. We are also seizing the opportunity of increasing our exports."

Only one other computer manufacturer, Burroughs, has so far announced price increases of its own; they will work out at an average of about 7.5 per cent. So far, no other companies have followed IBM and Burroughs, but the betting is that some-perhaps including English Electric-will have to do so within the next few weeks.

\section{Policy for Research}

THE British Government will shortly be issuing a long-awaited White Paper on research policy. At least one of the purposes of the White Paper will be to define ways in which the research establishments can help industry. Because there is plenty of room for disagreement-and misunderstanding-between the ministry and the industries it is trying to assist, the Electronic Engineering Association has got in first by producing a memorandum which sets out its own views on what the relationship should be. The report, which goes for discussion to the Development Council for the Electronics Industry next month, may differ in emphasis from the policy which the ministry must by now have agreed on. So far, though, any clashes between the association and the ministry are hypothetical.

The chief point which the report makes is that, when projects are jointly undertaken by government and industry, leadership should be very firmly in the hands of the industrial partners. Captain R. A. Villiers of the association points out that when research establishments were involved with military work they kept closely in touch with the military market, but the shift to civil work means that a new relationship with industry has to be worked out. He thinks that the ministry has much to learn by examining the records of other industrialized countries, which tend, among other things, to contract more work out to industry and to do less in the establishments. The main part the establishments can play on their own, he thinks, is in more basic research work-like, for example, the work on oceanography at Harwell.

Another idea which Captain Villiers puts forward involves the actual transfer of people from the establishments to industry and vice versa. Teams of people from the establishments should be able to join indus- trial firms, and teams from industry should be seconded to government establishments to pick up know-how. To do this, he says, both sides must become more flexible about transferring pension rights. But so far he seems confident that there is no clash of views between himself and the Government. Others will await the White Paper before committing themselves so cheerfully.

\section{Swiss Smelting}

THe Swiss Aluminium Company has submitted a tender to build an aluminium smelter in Britain. The company says the smelter could be built in 2.5 years at a cost of between $£ 18$ and $£ 20$ million and a maximum capacity of 100,000 tons. Other tenders have so far been made by Rio Tinto Zinc in conjunction with British Insulated Callender's Cables, by Alcan Aluminium of Canada and by British Aluminium. British Aluminium is jointly owned by Reynolds Metal Company of the United States and by Tube Invest ments.

The high cost of electricity in Britain has hitherto prohibited the development of a native aluminium smelting industry of any size. The decision by the British Government to invite tenders for a plant was made with the intention both of reducing imports and of creating new jobs in development areas. Tariffs being out of the question, the project is rendered commercially viable by the offer of cheap electricity and generous investment grants (see Nalure, 216, 109; 1967). The Board of Trade is prepared to grant these incentives to foreign and British companies without discrimination. The Government envisages the construction of two plants with a total capacity of 240,000 tons a year. It is hoped that the first will begin production in 1970 and the second in 1974.

\section{Sediments for Peace}

The Parliamentary Group for World Government, which is based in London, seems well launched on its campaign to bring international law and order to the bottom of the deep oceans. Earlier this week the group made public the membership of the committee which has been formed to study some of the problems of arranging that the resources of the deep oceans should be exploited "for the benefit of all mankind". The chairman of the committee is a barrister, $\mathrm{Mr}$ Maurice Bathurst, and the ordinary membership seems equally divided between lawyers, scientists and those with more general interests. Lord Ritchie-Calder is perhaps most accurately described as the founder member of the movement, for he was one of the first to urge, a year ago, that there should be a United Nations agency empowered to exploit the resources of the oceans and to spend the proceeds on international peace-keeping forces. Other members include Dr G. E. R. Deacon, director of the National Institute of Oceanography, Commandant Cousteau, director of the Institut Oceanographique at Monaco, Dr $\mathrm{T}$. Gaskell, of British Petroleum Ltd, and Mr Oscar Gugen of the World Underwater Federation. Dr Thor Heyerdahl has promised his support to the committee, which has alrcady met on two occasions and which is evidently prepared for a busy year ahead.

By all accounts, the committee will have to divide 